\title{
Canine Transitional Cell Carcinoma
}

National Cancer Institute

\section{Source}

National Cancer Institute. Canine Transitional Cell Carcinoma. NCI Thesaurus. Code

C128126.

A malignant neoplasm that affects dogs, arising from transitional epithelium. 